\title{
Correction to: Influence of anti- and prooxidants on rhizogenesis from hypocotyls of Mesembryanthemum crystallinum L. cultured in vitro
}

\author{
M. Libik-Konieczny ${ }^{1} \cdot$ M. Kozieradzka-Kiszkurno ${ }^{2} \cdot$ Ż. Michalec-Warzecha $^{1} \cdot$ Z. Miszalski $^{1} \cdot$ J. Bizan $^{3,4} \cdot$ R. Konieczny $^{4}$
}

Published online: 26 April 2019

(c) The Author(s) 2019

\section{Correction to: Acta Physiol Plant (2017) 39:166 \\ https://doi.org/10.1007/s11738-017-2466-x}

The original version of this article unfortunately contained a mistake. The Acknowledgement section of the article should read as:

Acknowledgements This work was financed by project funded by Polish Ministry of Science and Higher Education (no. 303356935).

Open Access This article is distributed under the terms of the Creative Commons Attribution 4.0 International License (http://creativeco mmons.org/licenses/by/4.0/), which permits unrestricted use, distribution, and reproduction in any medium, provided you give appropriate credit to the original author(s) and the source, provide a link to the Creative Commons license, and indicate if changes were made.

The original article can be found online at https://doi.org/10.1007/ s11738-017-2466-x.

M. Libik-Konieczny

libik@ifr-pan.krakow.pl

1 The Franciszek Górski Institute of Plant Physiology, Polish Academy of Sciences, Niezapominajek 21 St., 30-239 Kraków, Poland

2 Department of Plant Cytology and Embryology, University of Gdańsk, Wita Stwosza 59 St., 80-308 Gdańsk, Poland

3 Małopolska Centre of Biotechnology, Jagiellonian University, Gronostajowa 7A St., 30-387 Kraków, Poland

4 Department of Plant Cytology and Embryology, Institute of Botany Jagiellonian University, ul. Gronostajowa 9 St., 30-387 Kraków, Poland 